SRNL-STI-2013-00065, Rev. 0

Keywords: $M C U, A R P$, ISDP

Retention: Permanent

\title{
Sample Results from the Integrated Salt Disposition Program Macrobatch 6 Tank 21H Qualification MST Solids Sample
}

\section{T. B. Peters}

February 2013

Savannah River National Laboratory Savannah River Nuclear Solutions Aiken, SC 29808

Prepared for the U.S. Department of Energy under contract number DE-AC09-08SR22470. 
SRNL-STI-2013-00065, Rev. 0

\section{DISCLAIMER}

This work was prepared under an agreement with and funded by the U.S. Government. Neither the U.S. Government or its employees, nor any of its contractors, subcontractors or their employees, makes any express or implied:

1. warranty or assumes any legal liability for the accuracy, completeness, or for the use or results of such use of any information, product, or process disclosed; or

2. representation that such use or results of such use would not infringe privately owned rights; or

3. endorsement or recommendation of any specifically identified commercial product, process, or service.

Any views and opinions of authors expressed in this work do not necessarily state or reflect those of the United States Government, or its contractors, or subcontractors.

\section{Printed in the United States of America}

\section{Prepared for}

U.S. Department of Energy 
SRNL-STI-2013-00065, Rev. 0

\section{REVIEWS AND APPROVALS}

\section{AUTHORS:}

T. B. Peters, Author, SRNL/ACP

Date

TECHNICAL REVIEW:

C. A. Nash, Technical Reviewer, SRNL/ACP

Date

APPROVAL:

F. M. Pennebaker, SRNL/ACP, Manager

Date

S. L. Marra, SRNL/E\&CPT Research Programs, Manager

Date

M. T. Keefer, Tank Farm Facility Engineering, Manager

Date

E. J. Freed, DWPF Facility Engineering, Manager

Date

K. H. Subramanian, Flowsheet Integration Technology, Manager

Date 
SRNL-STI-2013-00065, Rev. 0

\section{EXECUTIVE SUMMARY}

Savannah River National Laboratory (SRNL) performed experiments on qualification material for use in the Integrated Salt Disposition Program (ISDP) Batch 6 processing. As part of this qualification work, SRNL performed an Actinide Removal Process (ARP) test. From this test, the residual monosodium titanate (MST) was analyzed for radionuclide uptake. The results of these analyses are reported and are within historical precedent. 
SRNL-STI-2013-00065, Rev. 0

\title{
LIST OF ABBREVIATIONS
}

\author{
ARP - Actinide Removal Project \\ ESS - extraction, scrub, strip \\ ICPES - Inductively Coupled Plasma Emission Spectroscopy \\ ICPMS - Inductively Coupled Plasma Mass Spectroscopy \\ ISDP - Integrated Salt Disposition Program \\ MST - monosodium titanate \\ SRNL - Savannah River National Laboratory \\ TTQAP - Task Technical and Quality Assurance Plan \\ TTR - Technical Task Request \\ $\%$ RSD - percent relative standard deviation
}




\subsection{Introduction}

This report details the results of the analysis of MST solids recovered from the ARP test. Results of supernate analysis for Salt Batch 6 qualification are previously reported. Previous documents ${ }^{1,2,3}$ cover initial and subsequent characterization which include analytical results. This work was specified by Task Technical Request (TTR) ${ }^{4}$ and by Task Technical and Quality Assurance Plan (TTQAP) in section 4.4. ${ }^{5}$

Details for the work are contained in a controlled laboratory notebook. ${ }^{6}$

For this macrobatch, Tank $21 \mathrm{H}$ is used as the blend and preparation tank. This material will be transferred to Tank $49 \mathrm{H}$ where it will be combined with the heel from Macrobatch 5. In this qualification effort for Macrobatch 6, only samples from Tank $21 \mathrm{H}$ have been analyzed. In this campaign, the qualification and tank strategy ${ }^{7}$ indicates that analysis of Tank $49 \mathrm{H}$ is not needed as the material was qualified for Macrobatch 5 . As long as the Tank $21 \mathrm{H}$ material is qualified, and the qualified Tank $49 \mathrm{H}$ material has not changed, then the blend of these two tanks will provide a usable composite.

\subsection{Experimental Procedure}

Six Tank 21H samples (i.e., dip sample bottles HTF-21-12-96, HTF-21-12-97, HTF-2112-98, HTF-21-12-99, and HTF-21-12-100, HTF-21-12-101, each containing approximately $200 \mathrm{~mL}$ ) arrived at SRNL in October 2012. The samples were optically clear, with no visible solids present. Researchers measured the density of each of the solutions (see Table 1). With customer concurrence, the samples were combined and mixed.

Table 1. Sample Density Measurements $\left(25^{\circ} \mathrm{C}\right)$

\begin{tabular}{|c|c|c|}
\hline Sample & Measured Density (g/mL) & $\begin{array}{c}\text { Sample Location } \\
\text { Height }^{\mathfrak{R}} \text { (inches) }\end{array}$ \\
\hline HTF-21-12-96 & 1.308 & 135 \\
\hline HTF-21-12-97 & 1.283 & 280 \\
\hline HTF-21-12-98 & 1.306 & 62 \\
\hline HTF-21-12-99 & 1.294 & 62 \\
\hline HTF-21-12-100 & 1.313 & 62 \\
\hline HTF-21-12-101 & 1.321 & 62 \\
\hline Average (\%RSD) & $1.304(1.05 \%)$ & \\
\hline
\end{tabular}

\footnotetext{
${ }^{\Re}$ This is from the bottom of the tank.
} 
As part of the salt batch qualification SRNL performed an Extraction-Scrub-Strip (ESS) test and an Actinide Removal Process (ARP) test. These results are reported separately. ${ }^{3}$ From the ARP test, SRNL isolated the MST solids by centrifugation and decant. The solids were not immediately removed after 8 hours due to the time required to isolate and remove the solids. However, a much longer delay also occurs in actual processing conditions at ARP.

\subsection{Analysis of MST Solids}

After the MST test completed, the MST solids were collected using centrifugation and the free liquid was carefully removed. This decant was filtered to inspect for solids and none were found. While the researchers tried to minimize the amount of supernate in the solids, we cannot eliminate or measure it. Personnel digested the retained MST solids (aqua regia/microwave) and sent them to Analytical Development for analysis. As it is problematic to attempt to isolate only the MST solids, SRNL digested the collected slurry and normalized all the results to titanium, giving a result in "pCi analyte/gram of titanium". To do this, we divided the analyte result in pCi by the grams of titanium from the digestate. Inductively Coupled Plasma Mass Spectroscopy (ICPMS), Inductively Coupled Plasma Emission Spectroscopy (ICPES), and various radiocounting methods were used for analysis.

As there are no, or virtually no, sludge solids in the feed material, the solids digestion data reflects the MST solids, and whatever adsorbs to the MST, as well as entrained/interstitial salt solution. Actinides and strontium adsorb to MST and the analysis of the MST provides relevant data for those species. However, the other results for materials that have limited affinity for MST are a function of material in the feed solution. Results for these elements are from interstitial or entrained salt solution. As there are no experimental data for many of these analytes as to whether or not they adsorb to MST under our conditions, SRNL cannot conclusively determine if the real values for an analyte result are from MST sorption or interstitial liquid entrainment. Therefore, the values reported in Table 2 should all be considered upper bounds.

All results were single results as there was not enough material to analyze duplicates. Values in parentheses are the analytical uncertainty. The exception to this is the ${ }^{241} \mathrm{Am}$ result, which is the average of two different analyses that both provided a result. In this case, the value in parenthesis is the \% RSD. 
Table 2. Tank 49H MST Solids Radiological Results

\begin{tabular}{|c|c|c|c|}
\hline Analyte & $\begin{array}{c}\text { Result } \\
\text { (pCi per gram of Ti) }\end{array}$ & Analyte & $\begin{array}{c}\text { Result } \\
\text { (pCi per gram of Ti) }\end{array}$ \\
\hline${ }^{233} \mathrm{U}$ & $<2.12 \mathrm{E}+05$ & ${ }^{147} \mathrm{Pm}$ & $<1.11 \mathrm{E}+06$ \\
\hline${ }^{234} \mathrm{U}$ & $<1.37 \mathrm{E}+05$ & ${ }^{151} \mathrm{Sm}$ & $<1.31 \mathrm{E}+06$ \\
\hline${ }^{235} \mathrm{U}$ & $1.97 \mathrm{E}+02(22.4 \%)$ & ${ }^{134} \mathrm{Cs}$ & $<4.22 \mathrm{E}+05$ \\
\hline${ }^{99} \mathrm{Tc}$ & $1.20 \mathrm{E}+06(11.7 \%)$ & ${ }^{137} \mathrm{Cs}$ & $3.99 \mathrm{E}+09(11.2 \%)$ \\
\hline${ }^{237} \mathrm{~Np}$ & $2.16 \mathrm{E}+04(22.4 \%)$ & ${ }^{144} \mathrm{Ce}$ & $<3.51 \mathrm{E}+05$ \\
\hline${ }^{238} \mathrm{Pu}$ & $8.84 \mathrm{E}+07(13.8 \%)$ & ${ }^{154} \mathrm{Eu}$ & $<4.03 \mathrm{E}+04$ \\
\hline${ }^{239 / 40} \mathrm{Pu}$ & $7.22 \mathrm{E}+06(13.9 \%)$ & ${ }^{155} \mathrm{Eu}$ & $<1.55 \mathrm{E}+05$ \\
\hline${ }^{241} \mathrm{Pu}$ & $<2.20 \mathrm{E}+07$ & ${ }^{226} \mathrm{Ra}$ & $<1.03 \mathrm{E}+06$ \\
\hline${ }^{242} \mathrm{Pu}$ & $<8.38 \mathrm{E}+04$ & ${ }^{238} \mathrm{U}$ & $4.48 \mathrm{E}+03(22.4 \%)$ \\
\hline${ }^{244} \mathrm{Pu}$ & $<3.88 \mathrm{E}+02$ & ${ }^{241} \mathrm{Am}$ & $3.11 \mathrm{E}+05(7.90 \%)$ \\
\hline Total Alpha & $<1.03 \mathrm{E}+08$ & ${ }^{242 m} \mathrm{Am}$ & $1.21 \mathrm{E}+03(93.3 \%)$ \\
\hline Total beta & $1.01 \mathrm{E}+10(14.1 \%)$ & ${ }^{243} \mathrm{Am}$ & $1.10 \mathrm{E}+04(30.8 \%)$ \\
\hline${ }^{60} \mathrm{Co}$ & $1.37 \mathrm{E}+04(29.5 \%)$ & ${ }^{242} \mathrm{Cm}$ & $9.99 \mathrm{E}+02(93.9 \%)$ \\
\hline${ }^{90} \mathrm{Sr}$ & $1.91 \mathrm{E}+09(13.9 \%)$ & ${ }^{243} \mathrm{Cm}$ & $<2.68 \mathrm{E}+04$ \\
\hline${ }^{94} \mathrm{Nb}$ & $<1.64 \mathrm{E}+04$ & ${ }^{244} \mathrm{Cm}$ & $1.63 \mathrm{E}+06(15.8 \%)$ \\
\hline${ }^{106} \mathrm{Ru}$ & $<1.86 \mathrm{E}+05$ & ${ }^{245} \mathrm{Cm}$ & $<2.20 \mathrm{E}+04$ \\
\hline${ }^{125} \mathrm{Sb}$ & $<1.40 \mathrm{E}+05$ & ${ }^{247} \mathrm{Cm}$ & $<2.63 \mathrm{E}+04$ \\
\hline${ }^{126} \mathrm{Sb}$ & $<1.75 \mathrm{E}+04$ & ${ }^{249} \mathrm{Cf}$ & $<2.81 \mathrm{E}+04$ \\
\hline${ }^{126} \mathrm{Sn}$ & $<1.36 \mathrm{E}+05$ & ${ }^{251} \mathrm{Cf}$ & $<2.56 \mathrm{E}+04$ \\
\hline & & & \\
\hline
\end{tabular}

${ }^{3} \mathrm{H},{ }^{14} \mathrm{C}$, and ${ }^{129}$ I results are not reported. As per the TTQAP, there were not enough solids to segregate a sample for contained digestion for these three analytes.

\subsection{Conclusions}

Analysis of the Tank $21 \mathrm{H}$ sample indicates that the material does not display any unusual characteristics. In conjunction with the previous reports, ${ }^{1,2}$ the Tank $21 \mathrm{H}$ material, when combined with the Tank $49 \mathrm{H}$ heel is acceptable for processing in the ISDP process. 
SRNL-STI-2013-00065, Rev. 0

\subsection{References}

${ }^{1}$ T. B. Peters and S. D. Fink, "Results of Initial Analyses of the Macrobatch 6 Tank 21H Qualification Samples,” SRNL-STI-2012-00685, Rev. 0, November 2012.

${ }^{2}$ T. B. Peters and S. D. Fink, "Sample Results from the Interim Salt Disposition Program Macrobatch 6 Tank 21H Qualification Samples,” SRNL-STI-2012-00707, Rev. 0, December 2012.

3 A. L. Washington II, T. B. Peters, S. D. Fink, "Sample Results from the Integrated Salt Disposition Program Macrobatch 6 Tank 21H Qualification MST and ESS Samples”, SRNL-STI-2013-00034, February 2013.

${ }^{4}$ S. E. Campbell, “Qualification of ISDP Salt Batch 6,” HLW-DWPF-TTR-2012-0012, October 30, 2012.

${ }^{5}$ T. B. Peters and S. D. Fink, "Task Technical and Quality Assurance Plan for ISDP Salt Batch 6 Sample Qualification,” SRNL-RP-2012-00625, Rev. 0, October 11, 2012.

${ }^{6}$ SRNL-NB-2012-00107, T. B. Peters, October 25, 2012.

${ }^{7}$ S. E. Campbell, "Qualification and Sampling Strategy for ISDP Batch 5 to Obtain Compliance to 512-S, DWPF, Tank Farm, and Saltstone Waste Acceptance Criteria”, X-ESR-H-00347, November 17, 2011. 